\title{
The Dyad Physical/Virtual Stores in the New Markets
}

\author{
Wenderson Fernandes Moura ${ }^{1}$, Leonardo de Lima Francisco ${ }^{1} \&$ Carlos Alberto Gonçalves ${ }^{1,2}$ \\ ${ }^{1}$ FUMEC University, Belo Horizonte, Minas Gerais, Brazil \\ ${ }^{2}$ Federal University of Minas Gerais, Belo Horizonte, Minas Gerais, Brazil \\ Correspondence: Wenderson Fernandes Moura, Av. Afonso Pena, 3880 - Centro, Belo Horizonte - MG, 30130-000, \\ Brazil. Tel: 55-31-99126-2030, 55-31-99752-2131.
}

Received: September 11, 2016

doi:10.5430/ijba.v7n6p10
Accepted: October 6, 2016

Online Published: November 2, 2016

URL: http://dx.doi.org/10.5430/ijba.v7n6p10

\begin{abstract}
This article aims to present the new role of physical retail stores in view of the current increase in e-commerce in Brazil, the so called "virtual stores". This is a very important theme for the sector, which will define the future of traditional retailing. Exploratory research was conducted in books, periodicals and other printed material pertaining to the subject. It was concluded that the understanding of the current scenario of retail and knowledge of the rapid growth of e-commerce are relevant factors to define new guidelines for retailers with physical stores. Another important factor observed in the study was that traditional retailers need to understand that customers have changed, they are increasingly aware of their rights and are more prepared to claim them, which makes these new consumers confident to make purchases through the Internet. Thus, these factors will be important to define the new position of traditional retail because the only certainty is that physical stores will have to reinvent themselves if they want to stay in business.
\end{abstract}

Keywords: traditional retail, physical/virtual stores (e-commerce), consumer habits

\section{Introduction}

The global retail market comprises a large group of stores, companies, distribution centers, merchandise portfolios, and services that target the consumer - be it from the perspective of Business to Business (B2B), or Business to Commerce (B2C). Before the well-known advances in information technology, traditional retail was done exclusively by physical stores and is considered one of humanity's oldest activities. It has developed over the years and has reinvented itself several times throughout history. It is now going through a moment marked by new developments as the competition which used to be on the other side of the street is now in the global system, in the increased array of offers, and in the demands and delivery services in highly elaborate networks. According to Ganesan et al. (2009), the current environment of traditional retail is marked by major trends that influence the practice of retailers in Brazil and in the world: these trends include practices of global supply, multi-channel routes for the markets, technologies, and innovations based on relationships. It is important to highlight that retail is the largest formal employer in Brazil with 3.7 million jobs generated in 10 years, which represents $20 \%$ of all formal jobs in the private sector, according to the Institute for Retail Development - IDV (2016).

As markets become progressively more competitive, to be attentive to customer loyalty is more and more important - which makes it necessary to cater to their needs, responses, in order to sustain and/or expand markets. In the model of strategic positioning of companies, the global markets greatly increase the offer of replacement products, new entrants, and the matrix of differentiation and costs also increases significantly. That is, over the last decades, retail organizations have gone through an intense rhythm of transformation, especially the upscaling movement of e-commerce in Brazil.

The so-called e-commerce, which has developed alongside the evolution of the internet in the world, is flourishing despite the reservations of a lot of traditional consumers. In Brazil, internet-based business has shown significant numbers of growth in a short period of time. The evolution of the internet allows for and fosters the appearance of new markets and, undoubtedly, is becoming one of the main channels of sales and distribution for organizations. To Hernandez (2002 apud Vieira, 2010), (Note 1) the ample development of electronic commerce in the last years requires that retail organizations have a strong distinction to attract and keep clients, because moving costs are lower 
on the internet when compared to conventional channels. The need for this development is justified by the increase in sales in electronic retail.

Thus, electronic retail commerce has conquered more and more space among commercial transactions, with a constant expectation that it could turn into a usual tool for buying and selling products and services. This kind of commerce encompasses the transactions effected between companies and consumers $(B 2 C)$. In what concerns business to consumer, despite the great diffusion of this new way of buying, there are still a lot of people who do not feel comfortable acquiring products and services through the web. Therefore, it is quite relevant to understand what may motivate an online visitor to become a consumer of the internet store, according to Garrán (2005), and this means identifying and analyzing which factors may be crucial in this transition which leads to effect the purchase via Web.

In light of the new concept of shopping, that is, "electronic commerce or e-commerce", traditional retailers need to reinvent and re-position themselves in the market in order to attract consumers once again and survive in face of this new reality of the world of commerce. This paper aims to present different authors' views regarding the positioning of physical retail stores and the variables (advantages and disadvantages) between electronic and traditional (physical stores) retail commerce in Brazil; moreover, it aims to identify the profile of new consumers in order to answer the question: what is going to be the new role of physical retail stores in face of the current growth of electronic commerce in Brazil?

\section{Theoretical Considerations}

Considering retail, the final link in the productive and distributional chain (an extremely dynamic sector and also sensitive to the environment given its direct interaction with consumers), understanding the current positioning of traditional retail is an important question for organizations that compete in the market, mainly with the advance of e-commerce.

\subsection{The Positioning of Current Physical Retail Stores}

To Ângelo (1994), of all human activities, commerce was one of the first to establish itself as a well-defined occupation. Besides the ones who traded, there were artisans who produced in small scale, which makes the binomial "buying and selling" one of the oldest activities in the world. With the advent of the Industrial Revolution and with mass and serial production, commerce gained force, opened new international frontiers and radically modified the world scenario. Through this evolution process, commerce developed to a physical environment, the creation of a human contact between seller and buyer gave the latter the opportunity to choose, discuss, and compare products, which brought more competition to the market.

Again according to Ângelo (2012), retail is not a sector in the economy but rather an activity that connects the producer of goods or services of different economic sectors and the final consumer. Retail gathers all activities related to the process of selling products and services and link producers and final consumers (Parente, 2000; Kotler \& Keller, 2005). Retail contemplates all activities related to the selling of products or services directly to the final consumer. According to Mattar (2011), retail encompasses a group of business activities that adds value to products and services sold. A retailer or a physical retail store is any commercial enterprise whose profit comes mainly from the sale of small lots in retail. Any organization that sells to its final consumers, be it a producer, wholesaler or retailer, no matter how or where the products or services are sold, does retail, according to Kotler and Keller (op. cit).

Retail with physical stores has faced a smaller growth due to the rapid growth of electronic retail (Mattar, 2011, p. 11). According to the institute for the development of retail - IDV (2016), whereas in the 90s crisis between 1997 and 2000, the six biggest bankruptcies or debt settlement agreements led to the extinction of 15 thousand vacancies and the closure of 400 stores belonging to the chains Mesbla, Mappin, Arapuã, Casa Centro and Lojas Brasileiras in 2015, 181 thousand vacancies were cut down and 100 thousand physical stores closed down.

According to the National Confederation for The Commerce of Goods, Services and Tourism - CNC (2016), the fall in the volume of retail sales in the last 15 years meant the closure of 95.4 thousand stores with employment bonds in 2015 , a result which corresponded to a recession of $13.4 \%$ in the commercial establishments that employ at least one employee. Even in face of a fall of $1.6 \%$ in sales in 2014, the sector still had registered the liquid opening of 11.4 thousand physical stores (Figure 1). 


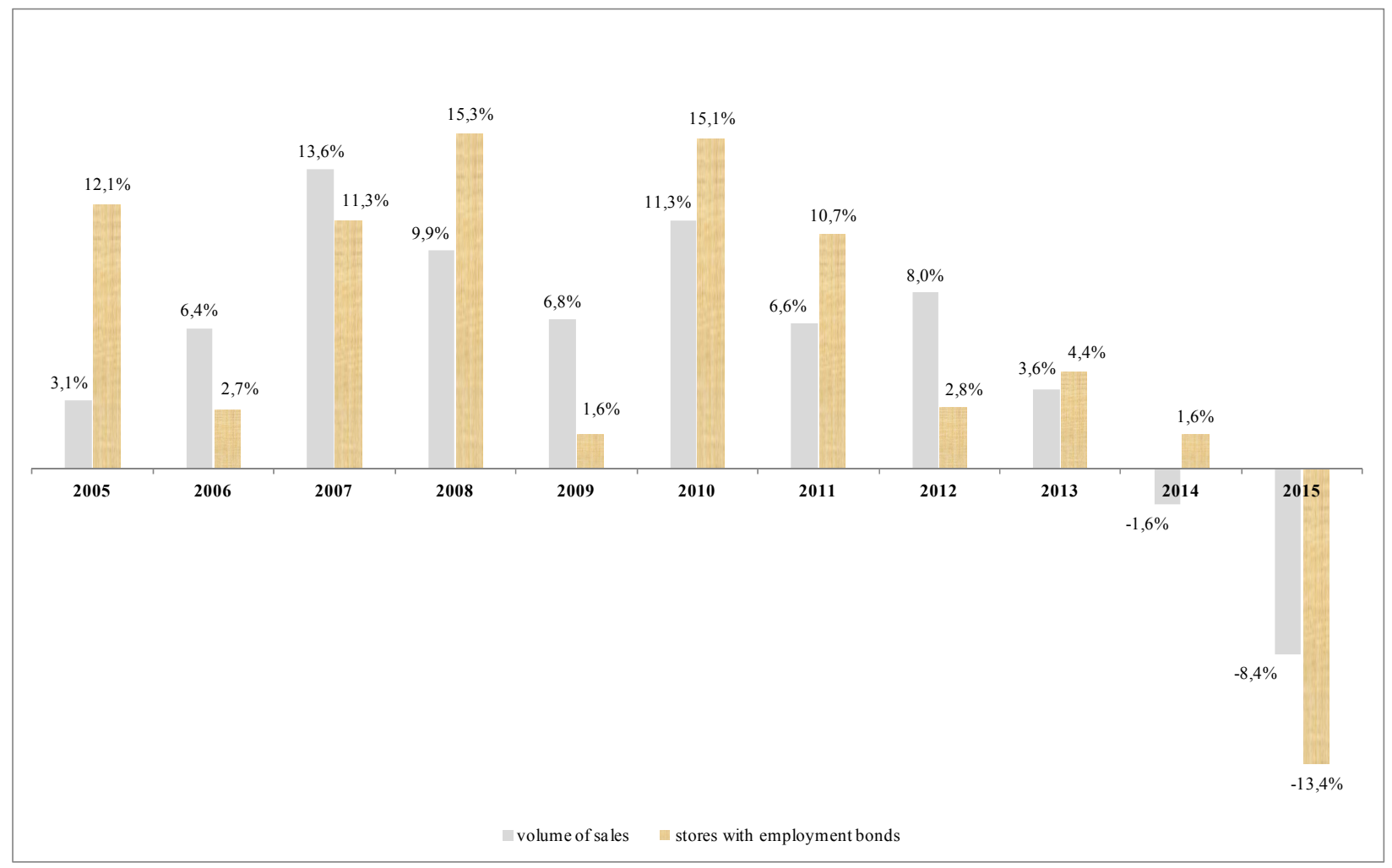

Figure 1. Percentual (\%) variations in the volume of sales and in the number of physical retail stores in 12 months (Percentual variation in relation to the same period of the previous year)

Source: Economic Division of the National Confederation of the Commerce of Goods, Services, and Services - CNC, 2016.

According to the Brazilian Institute of Geography and Statistic - IBGE (2016) through recent data from the Monthly Research in Commerce (PMC) regarding the period from January to November 2015, retail registered a fall of 4.0\% in its volume of sales considered in the restricted sense (fuels and lubricators; hypermarkets and supermarkets; foods, beverages and tobacco; fabrics, clothing, and footwear; pharmaceutical, medical and orthopedic items, fragrances and cosmetics; furniture and household appliances; equipment and stationery, informatics and communication; books, cultural articles; other retail-related products), which surpassed the reduction of $3.7 \%$ in 2003 , that is, it was the worst result since the beginning of the research. By contrast, in the broad sense, which includes results from the automotive industry and from construction, the fall was $8.4 \%$ in the same period (surpassing its first reduction registered in 2014 as $1.6 \%$ ).

It is important to underline that the PMC produces indicators that enable the follow up on the conjunctural behavior of retail commerce in Brazil, that is, this research investigates and assesses the re-sale net profit in the retail commerce organizations formally constituted, with 20 or more people involved. Still according to the CNC (2006), the research presented the highest reduction in the number of stores (-25.6 thousand) in relation to 2014, as far as hypermarkets, supermarkets and grocery stores (a segment that corresponds to one in each three commercial establishments) are concerned. Clothing and accessory stores represented $45.0 \%$ of the establishments that went out of business. Furthermore, big stores shrank $14.8 \%$, only staying behind medium-size establishments (-16.5\%) (Figure 2). 


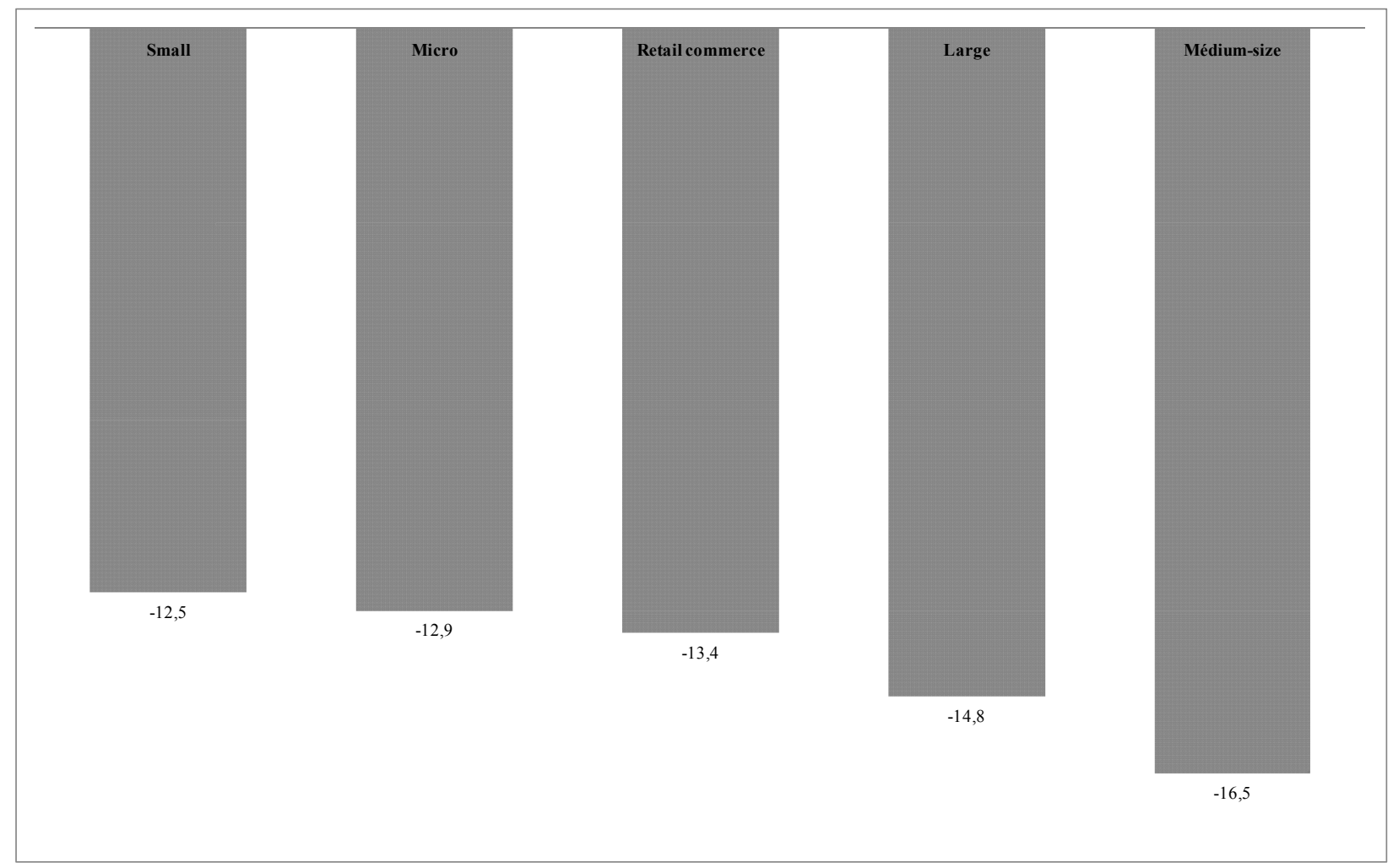

Figure 2. Percentual variations in the number of retail stores in 12 months according to size $(\%$ var. in relation to the same period in the previous year)

Source: Economic Division of the National Confederation of the Commerce of Goods, Services and Tourism - CNC, 2016.

According to CNC (2016), all retail segments revealed falls in the number of working movement informants, especially those segments which are more dependent on credit conditions such as: construction (-18.3\%), informatics and communication (-16.6\%), furniture and household appliances $(-15.0 \%)$ and automotive commerce (-14.9\%). The pharmacy and cosmetics segment was the only one to register significant growth in sales in 2014 . The 2015 retail crisis is evidenced on the regional plane, since out of the 27 states of the Federation only the state of Roraima did not show a fall in the number in retail establishments (CNC, 2016, p.3). Additionally, the states of São Paulo (-28.9 thousand), Minas Gerais (-12.5 thousand) and Paraná (-9.4 thousand) accounted, as a group, for $53.3 \%$ of the fall in the number of establishments (Figure 3).

From the data presented on the retail scenario in physical retail stores, we may assess the variables (advantages) and polarities between traditional retail and electronic commerce in Brazil. 


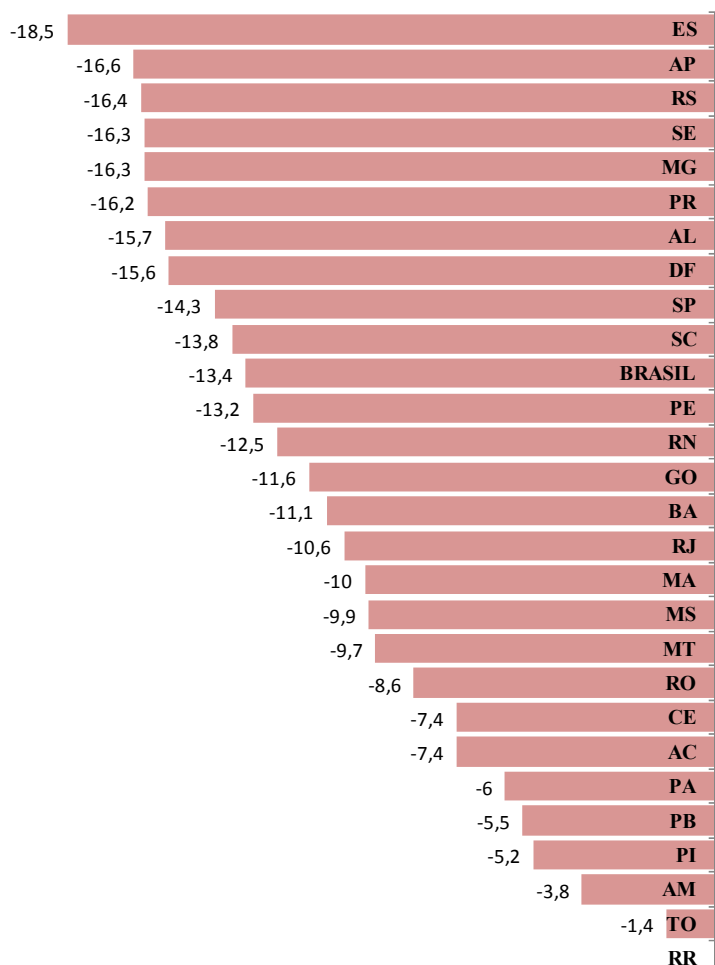

16,5

Figure 3. Percentual variations in the number of retail stores in 12 months according to the states of the Federation (var. \% in relation to the same period of the previous year)

Source: Economic Division of the National Confederation of the Commerce of Goods, Services and Tourism - CNC, 2016

\subsection{Electronic Commerce in Brazil, Advantages and Disadvantages}

According to Hernandez (2000 apud Vieira, 2010), the open development of electronic commerce in the last years requires that retail organizations have a significant distinction to attract and keep consumers inside the chain, granted that the moving costs are lower on the internet when compared to conventional channels.

The accelerated technological growth, coupled with the globalization impacts and with the current economic instability, increases the need for innovation, expansion of electronic commerce and also the diversification of the brands for new markets. To Kantar IBOPE Media (2015), consumer behavior in relation to technology presents similarities around the world as well as cultural specificities in each locale. As we analyze the activities on the internet in countries such as Brazil, Russia, India, China and South Africa, we may conclude that the habit of making purchases online is more evident in China (Figure 4). 


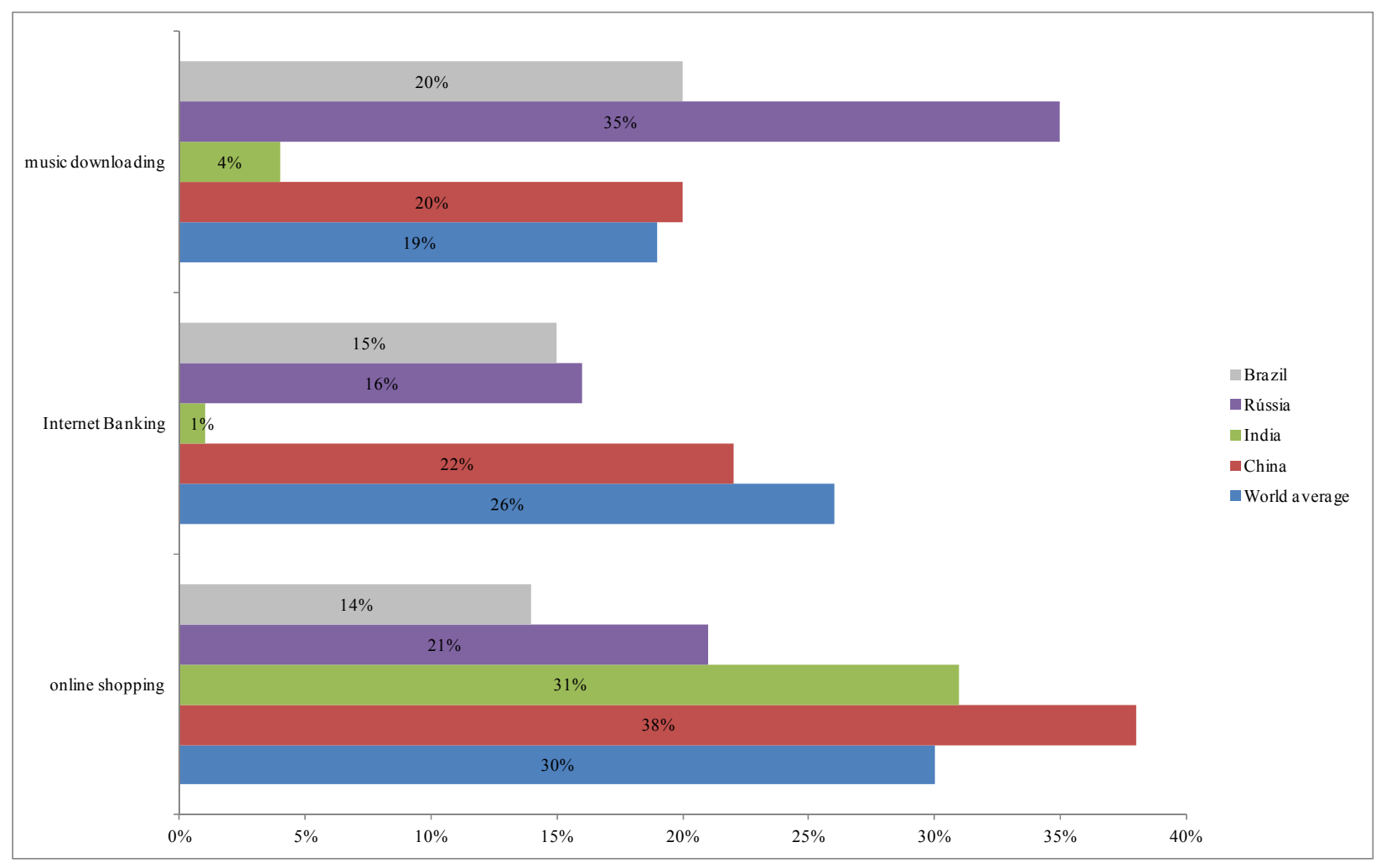

Figure 4. Comparison of activities among the countries Brazil, Russia, India, China, and South Africa Source: Kantar IBOPE Media, 2015

According to the Brazilian Research in Media - PBM (2015), almost half (48\%) of the Brazilians use the internet regularly. The percentual of people that utilize the internet everyday has grown from $26 \%$ on PBM 2014 to $37 \%$ on PBM 2015. Moreover, the internet also has a good rate of exclusive attention since $32 \%$ of the users do not perform any other task when connected, such as eating, talking, or watching TV. Still according to PBM/2015, users utilize the internet mainly to get informed (news bulletins or information in general), to have fun, to spend free time and to study. The research also shows that the youngsters are the most assiduous users of this media, since $65 \%$ of the users on the group between 16 to $25 \log$ on every day. These data presented by PBM/2015 offer a profile of the internet users in the country as a mass of potential online consumers. Retail organizations have noticed that the internet is an opportunity to boost sales with the possibility of reducing costs.

According to Bergamo and Giuliani (2007), retail has shown significant growth rates, maintaining its status as one of the largest sectors in world economy. To many authors and specialists, electronic commerce - an almost non-existent modality ten years ago - is directly responsible for this growth. Electronic retail is the direct sale to the final consumer through the internet by means of the supplier's virtual store (Mattar, p. 573, 2011).

The home-originated purchase has become particularly attractive, big collective shopping sites have begun operating on the Brazilian on-line market and consumers have adhered to this new form of shopping. From this moment on, there emerged storeless retail. Levy and Weitz (2000) affirm that the most exciting and potentially most significant storeless retail is home-originated interactive shopping, also known as storeless retail or electronic retail. What with the increase of storeless retail in Brazil, especially with the growth of the United States in the same sector, retail involving physical stores has begun to change since these stores had to begin a new process of market study and analysis, aiming at getting ready for this new competitor.

According to Nielsen Ibope (2006), e-commerce, as part of the eco-system of on-line retail, is becoming a phenomenon that allows consumers from all over the world to have unprecedented access to products. According to the study "Connected Global Commerce", today in Brazil 9 out of 10 people (96\%) have already made purchases on-line, Latin America being one of the fastest-growing markets in e-commerce, with a penetration of $23 \%$. 
The main retail stores in the country have created their own sites where they have begun to sell also through the web and have met with a market of great potential and which has become a large business for organizations. To Vasconcelos (2005), electronic markets show how technology utilizes the internet to allow for the creation of new models of business hitherto non-existent.

It is important to highlight that electronic commerce is not restricted to the sales of products and services to a final consumer through virtual stores on the internet. In fact, electronic commerce encompasses countless forms of making transactions, be they financial, information, product or service-based, so as to reduce costs, increase process-efficiency, eliminate intermediaries and communication obstacles (Almeida, 2014). According to Albertin (2010), electronic commerce has a strategic potential to provide companies operating in the market with cost benefits, diversification of products and services, the possibility to improve the relationship with the customer and it also enables the introduction of replacement products and allows for new competitive strategies with the use of technology.

Retail in Brazil has always shown great creative capacity for innovation, due to the need for survival in such an unstable economy. To Parente (2000), the frequency of changes in retail are greater when motivated by the increase of foreign investments (globalization), the increase in the concentration of market by big retailers and the greater specialization of organizations. Aladay and Pinochet (2002, apud Bergamo and Giuliani, 2007), point out that Brazilian retail has never changed as much as after the incorporation of new information systems in these organizations. In this scenario of constant evolution, transformations and change, it was not difficult for retail organizations to naturally absorb the need to keep operations on the internet, to satisfy the growing demand for services of this nature (Bergamo \& Giuliani, p. 3, 2007). It is worth recalling that electronic commerce has advantages (benefits) and disadvantages that must be taken into consideration.

Among the benefits presented by Albertin (2010), the one that most strengthens electronic retail is the reduction in operational costs such as: payroll, taxes, rent, storage, and utilities. That is, the costs mentioned represent a high level of participation in the composition of the final price offered to the consumer. According to Sheth (2002) the costs should not be the only factors to determine prices, but they really play a primary role. The product price is nowadays one of the factors that make the consumer shop on the internet, a more attractive setting with a variety of low prices and forms of payment that facilitate the acquisition of products. Another factor that benefits electronic retail has to do with diversity, the capacity of an individual to buy products from the most diverse market segments through the use of the internet. According to Rodrigues (1998), the digital era brings with it an avalanche of products and services to seduce consumers from all over the world.

To Bergamo and Giuliani (2007), electronic retail has both advantages and disadvantages in comparison with traditional retail (physical stores) to the consumer and organization, which are pointed out as follows:

- Advantages to the consumer: availability of access to the store 24 hours a day; more details and information about the product; research about the retail company; potentially lower price of the product and service; convenience at the time of shopping and upon delivery, payment facilities, among others.

- Advantages to the organization: the irrelevance of location and size; low operational costs; wide reach to the target-audience; higher income profile of the consumers; store open all the time; more opportunities for the realization of the Customer Relationship Management - CRM.

- Disadvantages to the consumer: the impossibility to have contact with the product before the purchase; the waiting time for the receipt of a product; low negotiation level due to the absence of a seller.

- Disadvantages to the seller: lower management know-how; more complex logistics; low rate of impulse buys; incipient legislation; non-adaptability of the expertise of traditional retail; pressure in the price range of the stores; more difficult post-sale (especially for international sales).

To Neto, Lima and Carvalho (2012), the main possible advantages and disadvantages of electronic retail are:

- Advantages: possibility to compare prices from different retailers; possibility of product research; prices generally lower than in traditional retail; greater agility in the search for products from different retailers; purchase process relatively simpler (order and delivery of purchase); greater convenience to consumers; high level of interactivity with clients; it generates visibility and strengthens the relationship in business; power of response from the company to the customers (the information requests can be responded to more quickly on the company site); cost reduction; just-in-time stock; relevance of information technology; distribution channels can expand with a virtual showroom; expenses to open a virtual showroom are lower 
than to open a physical store; more flexibility; automatic sales in response to the orders; expansion of the promotional mix of the company; and opportunity to test new products and services.

- Disadvantages: lack of reliability in the payment forms available to the consumers; possible delay in the delivery of products (logistics); it does not put clients in total contact with the products; the absence of a "salesperson" who would act to influence in the purchase process; difficulty in the case of product replacement if a product is faulty, etc; it does not allow the consumer to try on or test the product (the contact is visual in most cases); the large number of stores in operation; distribution and delivery of products at the customers' residences (virtual retail obstacle); not all products or services are appropriate to exhibition and sale on the web; although capital expenses may be reduced, offers, communications, and maintenance require several hours, days or weeks (web professional); the promise of 24-hour service may have serious repercussions if the service presents failure; the company cannot be sure about who the buyer is and what his intentions are; the consumer can have doubts regarding the company and what it represents.

Retail is an interesting arena as an object of inquiry. Several scholars, specialists, and practitioners guarantee that most of the shopping decisions take place at the moment of sale, which increases even more the importance of this chain agent. In light of the advantages and disadvantages of electronic commerce, it is important to understand the reasons, demands, and the consumers' profiles, so traditional retail organizations (physical stores) may look to define the strategies to be adopted to meet challenges.

\subsection{The New Consumer Profile in Retail Physical and Online Stores}

Interaction must be inherent to all the processes by which companies relate to their customers since it allows all the channels to have two directions, that is, it provides customers with information and it also takes information to the company from these customers. This allows customers to have an active attitude as to their relationship with the organization and not only receive the products, services, and information passively (Albertin, 2010).

In order to understand the consumer it is necessary to know him/her, that is, it is necessary to assess the aspects that influence their shopping decisions. Both in retail with or without physical stores the relationship management tool is utilized to facilitate comprehension. According to Abertin (2010), relationship management (Customer Relationship Management - CRM) is the organizational practice that manages the forms of relationship with customers, be they legal entities or persons. With a well-conceived CRM it is possible to know who is buying and their possible buying motivations.

Storeless retail has one advantage in the development of CRM, since through data that customers themselves insert on the web, it is possible to know their preferences. According to Catalani et. al. (2007), surveys are extremely useful tools to measure customer satisfaction and their purchase experience. By contrast, in retail with physical stores the development of a relationship with the customer is intimately linked with the roots of retail, through the knowledge of the surrounding community, the identification of primary, secondary, and tertiary zones of the business, the permanent conduction of satisfaction surveys, and the knowledge of competitors.

Li and Zhang (2002) have conducted a study with the purpose to identify the main purchase antecedents of on-line products consumers through a research into several works concerning the theme; Fig. 5 below presents an evaluation model to understand the behavior of the on-line retail consumer. 


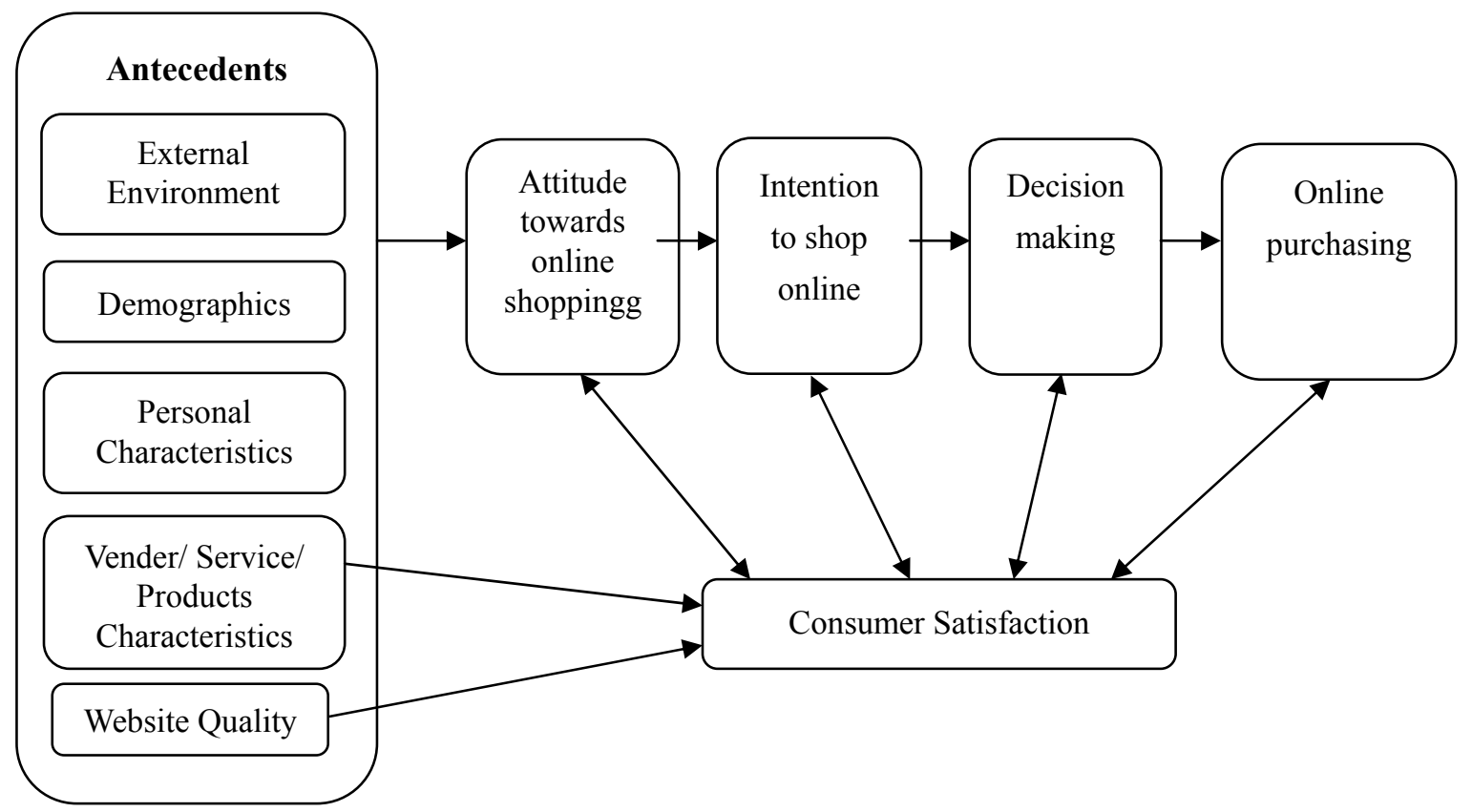

Figure 5. Conceptual Inner Model for evaluating the satisfaction of on-line retail consumer

Source: elaborated by Li and Zhang, 2002.

Still according to the aforementioned Li and Zhang (2002), the model that evaluates satisfaction, represented by Figure 5, comprises the following variables: external environment (competition, consumer protection norms), demography (age group, gender, education level, income and time spent on-line), personal characteristics (knowledge about the internet, lifestyle, values, and cultural environment), characteristic related to the product and service (store reputation, warranties, size of the store (facility of use, promotions, privacy and security), attitudes towards on-line shopping, on-line shopping intentions, decision-making (the phase before consumers commit to making the purchase transaction), on-line shopping and consumer satisfaction. The model describes and outlines the relationships among the variables.

The first antecedent is the external environment, where the consumer seeks to shop on safe sites, those that guarantee his/her rights, besides the competition that allows him/her to search for the product in different companies without leaving their home. The demographic factors are relevant to know the kind of shoppers the authors identified, such as the youngest ones, the ones with higher education level and economic power. The personal characteristics of on-line consumers constitute the third antecedent that characterizes them as clients motivated more by convenience than by the experience. The sale, the service and the products characteristics significantly affect the shopping intention because on-line consumers assess what companies can offer in terms of benefits and the quality of the products through surveys. The website quality is another important factor in the purchase decision of on-line consumers.

The antecedents presented by Li and Zhang (2002) generate purchase attitudes, motivations and its final realization and their aim is to promote the satisfaction of virtual stores consumers. They reinforce the importance of knowing the customer well as a factor of survival of any retail business, be it with or without physical stores. The companies that manage to create a good relationship with their clients, knowing their profile, seeking to meet their expectations, will be ahead in the market.

\section{Final Considerations}

Although retail involving physical stores is in its majority the first shopping option for the consumer, it is necessary to attend to the accelerated growth of electronic commerce in Brazil. Each year this market proves that it has come to stay and can, in the future, replace traditional retail or contribute cooperatively with it. It may already be noted that there is a conflict between the prices of physical and online stores, the latter of which many times show lower prices, which allows comparisons among the many suppliers. This is a major drawback to the physical store. 
And what will be the new role of physical retail stores? This is also an interrogation under scrutiny; however, according to Sheth (2002), consumers, in a very near future, will go to physical stores for pleasure and not only with the purpose to shop because they will be able to do it via phone, internet, etc.

In light of the results presented in this paper, it may be inferred that retail in its essence remains the same performing the task it has historically been associated with since the first contacts among human beings, that is, a task that turned to providing human societies with subsistence in a context of exchange of goods and services among people which is based in some form of commerce. The customer still consumes by his/her own need; however, although the essence of retail is in the consummation of the sale, it is necessary to evolve with the market to transform conventional sale sites into something of value for the client.

From this research of an exploratory character it was concluded that the understanding about the current scenario of retail and the knowledge about the accelerated growth of electronic commerce are relevant factors to define new guidelines for retail with physical stores. Another important factor observed in the study was that traditional retail needs to understand that the customer has changed and is increasingly aware of his/her rights and also more prepared to claim them, which makes this new consumer more confident to make purchases through the internet.

It is, therefore, taken as a consequence of growth of the virtual market a decrease in sales performance of traditional retail (physical stores) regardless of how big a company is, in comparison to online retail (e-commerce). The main conclusions to this study infer that sales through physical stores are motivated by satisfaction needs, fulfilling what causes the consumer to make the purchase, depicting and evaluating the change of consumer's profiles in today's social context, and the creation of organizational frameworks that maintain and grasp costumers. (Bergamo \& Giuliani, 2007; Almeida, 2014; CNC 2015)

The great challenge to traditional retail, not considering the advantages of virtual stores with lower maintenance costs, 24 hour availability, autonomy to customizable services attending different costumer needs, adding up to the decision of the purchase, higher satisfaction value, and the costumer's own satisfaction in the act of the purchase. The physical stores should provide a unique purchase experience to the costumers.

The growth of virtual retail through e-commerce does not mean the end of physical purchases or stores, it only provides other means of acquisition to consumers of traditional retail, fulfilling a market void, mainly through interaction, agility, and autonomy, which virtual retail provides. Li and Zhang (2002), state that one of the factors that serve as a parameter to measure on-line sales is the real existence and location of physical stores. Demonstrating the importance of physical stores as an experience that comes prior to the virtual one, or even serving as a reference to on-line shopping.

As for possible developments from the reflections presented here and regarding future researches, future studies could examine what conditions of physical stores operating in the retail market (level of competition of the sector, economic conditions, level of uncertainty in the environment, value incorporation for the customer) and what internal conditions of the organization (size, participation in the market, level of innovation, process improvements) are correlated and influence results in a context of retail practice in contrast with virtual stores. Thus, these studies could empirically test the validity of the theoretical propositions here presented (applied specifically to the Brazilian scenario.

Furthermore, it is suggested that the effect of competitive strategies adopted by organizations (physical stores) be verified as an antecedent to the challenges faced in relation to e-commerce.

\section{References}

Albertin, A. L. (2010). Comércio eletrônico: modelo, aspectos e contribuições de sua aplicação (6. ed.). São Paulo, SP: Atlas.

Almeida, M. R. (2014). O varejo virtual na realidade do consumidor e lojas físicas no Brasil. Periódico Científico Negócios em Projeção, 5(2), 1-19.

Ângelo, C. (1994). Varejo Modernização e perspectivas. São Paulo: ATLAS.

Ângelo, C. (2012). O varejo no Brasil e no mundo. In Ângelo, C., Nielsen, F., \& Fouto, N. (Eds.), Manual de Varejo no Brasil, Orgs. São Paulo: Saint Paul Editora.

Bergamo, F. V. M., \& Giuliani, A. C. (2007). Estratégias de Marketing para o Varejo Eletrônico: um novo modelo. In: XXXII Encontro Anual da Associação Nacional de Programas de Pós-Graduação e Pesquisa em Administração (ANPAD), 32, 2007. Rio de Janeiro. Anais do ENAPAD 2008. Rio de Janeiro. 
Catalani, L. et al. (2007). E-Commerce. Rio de Janeiro: FGV.

CGI.BR. (2010). Pesquisa sobre o uso das tecnologias da informação e da comunicação no Brasil: TIC domicílios e TIC empresas 2009. São Paulo: Comitê Gestor da Internet no Brasil.

Confederação Nacional Do Comércio De Bens, Serviços E Turismo - CNC. (2015). Crise no varejo provoca fechamento recorde de lojas em 2015. Retrieved May 02, 2016, from http://www.cnc.org.br/sites/default/files/arquivos/balanco_fechamento_de_lojas_em_2015.pdf

Dornelas, H. M., Deitel, P. J., \& Steinduhler, K. (2004). E-business e e-commerce para administradores. São Paulo: Person Education do Brasil.

Ferreira, N. S., \& Yoshida, E. M. P. (2004). Produção Científica sobre psicoterapias breves no Brasil e demais países latino-americanos (1990-2000). Estudos de Psicologia, 3(3), 523-531. http://dx.doi.org/10.1590/s1413-294x2004000300015

Ganesan, S., George, M., Jap, S., Palmatier, R., \& Weitz, B. (2009). Supply Chain Management and Retailer Performance: Emerging Trends, Issues, and Implications for Research and Practice. Journal of Retailing, 85(1), 84-94. http://dx.doi.org/10.1016/j.jretai.2008.12.001

Garrán, V. G. (2005). De navegadores a compradores: os elementos motivacionais nas decisões de compra pela internet. Revista Contemporânea de Economia e Gestão, 3(1), 45-53.

Gouvêa, M. A., Oliveira, B., \& Veríssimo, H. U. D. S. (2014). O relacionamento entre o valor, a preferência e a intenção de compra no varejo online. Revista Administração FACES Journal Belo Horizonte, 13(1), 25-45.

IBGE - Instituto Brasileiro De Geografia E Estatística. (2016). Pesquisa Mensal de Comércio - PMC. Retrieved May 01, 2016, from http://www.ibge.gov.br/home/estatistica/indicadores/comercio/pmc/.

Instituto Para Desenvolvimento Do Varejo - IDV. (2016). Análise do PMC. Retrieved May 08, 2016, from http://www.idv.org.br/images/upload/IDV_2016_03_Analise_PMC.pdf

Instituto Para Desenvolvimento Do Varejo - IDV. (2016). Varejo só recupera perdas da crise em 2021. Retrieved May 01, 2016, from http://www.idv.org.br/idv-na-midia/varejo-so-recupera-perdas-da-crise-em-2021/

Kantar Ibope Media. (2016). Consumidor conectado: Semelhanças e diferenças ao redor do mundo. Retrieved May 08, 2016, from https://www.kantaribopemedia.com/consumidor-conectado-semelhancas-e-diferencas-ao-redor-do-mundo/

Kotler, P., \& Keller, K. (2005). Administração de marketing (12 ed.). São Paulo: Pearson Prentice Hall.

Levy, M., \& Weitz, B. A. (2000). Administração de Varejo. São Paulo: Atlas.

Li, N., \& Zhang, P. (2002). Consumer online shopping attitudes and behavior: An assessment of research. AMCIS 2002 Proceedings, 74.

Mattar, F. N. (2011). Administração de varejo. Rio de Janeiro: Elsevier.

Neto, O. N., Lima, G. B., \& Carvalho, D. T. (2012). Estratégia de Varejo Tradicional com Loja complementada com E-commerce: O Caso Francói Presentes. Florianópolis: Encontro de Estudos sobre Empreendedorismo e Gestão de Pequenas Empresas.

Nielsen Ibope. (2006). Estudo Comércio Global Conectado. Retrieved May 08, 2016, from http://www.nielsen.com/br/pt/insights/reports/2016/Estudo-Global-Comercio-Conectado.html

Nielsen Ibope. (2016). E-commerce cresce no Brasil principalmente para bens duráveis. Retrieved May 10, 2016, from

http://www.nielsen.com/br/pt/insights/news/2016/E-commerce-cresce-no-Brasil-principalmente-para-bens-dura veis.html

Parente, J. (2000). Varejo no Brasil: Gestão e Estratégia. São Paulo: Atlas.

Porto, R. M., \& Miotto, A. P. S. C. (2007). Integrar ou Separar Lojas Físicas e Virtuais? A Estratégia Clicks-and-Mortar no Varejo de Livros. In: XXXII Encontro Anual da Associação Nacional de Programas de Pós-Graduação e Pesquisa em Administração (ANPAD), 32, 2007. Rio de Janeiro: Anais do ENAPAD 2008. Rio de Janeiro.

Richardson, R. J. (2008). Pesquisa social: métodos e técnicas (3. ed.). São Paulo: Atlas. 
Rodrigues, V. (1998). Varejo na era digital. Seu novo negócio está mudando: Você já sabe o que fazer. São Paulo: Editora Globo.

Secretaria De Comunicação Social Da Presidência Da República. (2015). Pesquisa Brasileira de Mídia - PBM 2015: levantamento quantitativo domiciliar sobre os hábitos de consumo de mídia pela população brasileira. Retrieved May 08, 2016, from http://www.secom.gov.br/atuacao/pesquisa/lista-de-pesquisas-quantitativas-e-qualitativas-de-contratos-atuais/pe squisa-brasileira-de-midia-pbm-2015.pdf/view

Sheth, J. N. (2002). Marketing na Internet. São Paulo: Bookman.

State of Connectivity. (2016). A Report on Global Internet Access. Retrieved May 08, 2016, from https://fbnewsroomus.files.wordpress.com/2016/02/state-of-connectivity-2015-2016-02-21-final.pdf

Turban, E., Mclean, E., \& Wetherbe, J. (2004). Tecnologia da informação para gestão: transformando os negócios na economia digital (3. ed.). Porto Alegre, RS: Bookman.

Vieira, V. A. (2002). As tipologias, variações e características da pesquisa de marketing. Revista da FAE, Curitiba, 5(1), 61-70.

Vieira, V. A. (2010). Mensuração da qualidade de serviço no varejo eletrônico e seu impacto sobre as intenções comportamentais. RAE- Revista de Administração de Empresas, 50(2), 199-214. http://dx.doi.org/10.1590/S0034-75902010000200006

\section{Note}

Note 1. Most bibliographic references consulted for this study are in Portuguese; excerpts have been either paraphrased or translated by the authors, who are responsible for the English version of the paper. 